\title{
HUBUNGAN LAMA MEROKOK DENGAN KEJADIAN HIPERTENSI DI PUSKESMAS KENYARAN KECAMATAN PANTAN CUACA KABUPATEN GAYO LUES TAHUN 2019
}

\author{
Dewi Ramadani ${ }^{1}$, Hamidah ${ }^{2}$ \\ STIKes Rumah Sakit Haji Medan, Indonesia
}

\begin{tabular}{|c|c|}
\hline Article Info & ABSTRACT \\
\hline & $\begin{array}{l}\text { Hypertension is the silent disease because people do not know that } \\
\text { they are exposed to hypertension due to prolonged smoking. The } \\
\text { purpose of this study is to determine the relationship between } \\
\text { smoking duration and the incidence of hypertension in Kenyaran } \\
\text { Health Center, Pantan Weather, Gayo Lues Regency in 2019. This } \\
\text { type ofresearch is quantitative research, The research design used is }\end{array}$ \\
\hline Keywords: & descriptive correlation with cross sectional approach. The population \\
\hline $\begin{array}{l}\text { Duration of Smoking } \\
\text { Hypertension }\end{array}$ & $\begin{array}{l}\text { in this study was hypertension sufferers. The total sampling } \\
\text { technique was } 30 \text { people. Chi-square test results obtained a }\end{array}$ \\
\hline & $\begin{array}{l}\text { significant value } \mathrm{P} \text { value }(0.001)<(0.05) \text { there is a significant } \\
\text { relationship between the duration of smoking with the incidence of } \\
\text { hypertension in Kenyaran Public Health Center in Pantan Weather } \\
\text { Gayo Lues District in } 2019 \text {. The conclusion of this study is that } \\
\text { cigarettes contain nicotine which can increase the hormone } \\
\text { epinephrine which can constrict arterial blood vessels. It is } \\
\text { recommended to health workers to provide counseling about the } \\
\text { dangers of smoking for people with hypertension. }\end{array}$ \\
\hline
\end{tabular}

\begin{abstract}
This is an open access article under the CC BY-SAlicense.

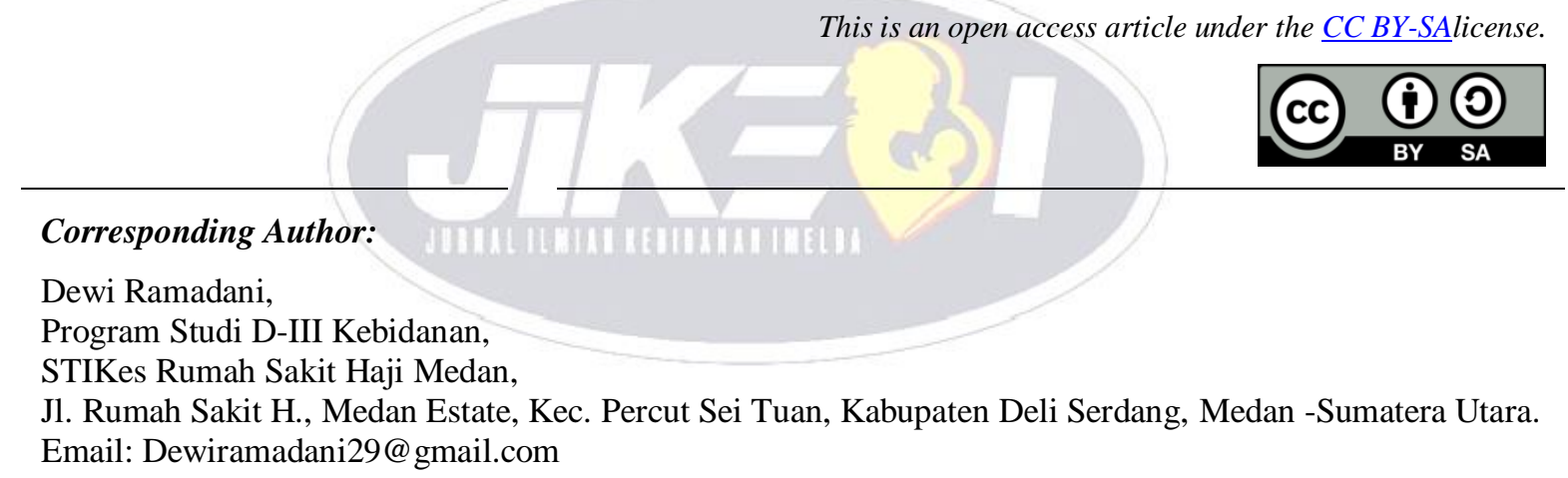

\section{INTRODUCTION}

Tekanan darah tinggi atau hipertensi berarti tekanan tinggi didalam arteri. Arteri adalah pembuluh yang mengangkut darah dari jantung yang memompa keseluruh jaringan dan organ-organ tubuh. Tekanan darah tinggi bukan berarti teganggan emosi yang berlebihan, walau teganggan emosi dan stress dapat meningkatkan tekanan darah untuk sementara. Tekanan darah normal adalah dibawah 120/80, tekanan darah antara 120/80 dan 139/89 disebut “pra-hypertension' (pre-hypertension) dan suatu tekanan darah dari 140/90 atau diatasnya dianggap tinggi (Irianto, 2015).

Hipertensi merupakan keadaan peningkatan tekanan darah dalam arteri ketika jantung sedang berkontraksi (sistolik) sama dengan atau diatas $140 \mathrm{mmHg}$ dan tekanan darah saat jantung sedang berelaksasi (diastolik) sama dengan atau diatas $90 \mathrm{mmHg}$ (WHO, 2013). Hipertensi adalah salah satu faktor penting sebagai pemicu penyakit tidak menular (Non Communicable Disease = NCD) seperti penyakit jantung, 
Stroke, dan lain- lain yang saat ini menjadi momok penyebab kematian nomer satu di dunia (Kemenkes RI, 2015).

Penyakit hipertensi merupakan the silent disease karena orang tidak mengetahui dirinya terkena hipertensi sebelum memeriksakan tekanan darahnya. Hipertensi merupakan penyebab terbesar dari kejadian stroke, baik tekanan darah sistolik maupun diastoliknya (Rudianto, 2013).

Diperkirakan telah menyebabkan 30\% dari kematian di seluruh dunia dan prevalensinya sebesar 37,4\%. Dari berbagai survei di dapatkan dalam 10 tahun terakhir prevelensi hipertensi meningkat secara bermakna. Hipertensi merupakan penyumbang kematian akibat penyakit tidak menular (PTM) yang meningkat dari 41,7\% menjadi 60\% survei terakhir di Indonesia menunjukkan PTM mendominasi 10 urutan teratas penyabab kematian pada semua kelompok umur, dengan stroke yang merupakan komplikasi hipertensi sebagai penyabab kematian nomor satu (Kementrian Kesehatan, 2013). Bahaya penderita hipertensi di perkirakan sebanyak 15 juta bangsa Indonesia tetapi hanya 4\% yang terkontrol berarti mereka yang menderita hipertensi dan tahu mereka menderita hipertensi. Lebih di kemukakan 50\% penderita tidak menyadari dirinya sebagai penderita hipertensi karena itu mereka cenderung menderita hipertensi yang lebih karena tidak berubah dan menghindari faktor resiko (Abidin \& Nawi, 2011).

Di Indonesia, jumlah kematian akibat penyakit yang disebabkan dari kebiasaan merokok mencapai 300 ribu pertahun. Hampir 60 persen kematian di Indonesia disebabkan oleh penyakit tidak menular (PTM) yang disebabkan oleh rokok seperti stroke, hipertensi dan penyakit jantung yang kini jumlahnya semakin meningkat. Hal tersebut, merupakan ancaman bagi pertumbuhan ekonomi, karena PTM yang semula terjadi pada usia lanjut kini mulai menyerang pada usia yanglebih muda. Prevalensi perokok di Indonesia, dengan usia di atas 15 tahun pun terus meningkat. Perokok dengan usia 5 tahun berdasarkan Riskesdas tahun 2010 terjadi di beberapa provinsi dan yang terbesar ada di Jawa Timur, Jawa Tengah, Jawa Barat, DI Yogyakarta dan Sumatera Selatan (Juliyah, 2012).

Dari 33 propinsi di Indonesia terdapat 8 propinsi yang kasus penderitanya hipertensi melebihi ratarata nasional yaitu: Sulawesi Selatan (27\%), Sumatera Barat (26\%), Jawa Timur (25\%), Sumatera Utara (24\%), Sumatera selatan (24\%), Riau 23\% dan Kalimantan Timur 22\%. Sedangkan dalam perbandingan kota di Indonesia kasus hipertensi cenderung tinggi pada daerah urban seperti: Jobadetabek, Medan, Bandung, Surabaya dan Makassar yang mencapai 30-34\% (Eka, 2011 Dalam Dewi, 2013).

Berdasarkan data awal yang diambil di Puskesmas Kenyaran Kecamatan Pantan Cuaca Kabupaten Gayo Lues tanggal 02 bulan Januari tahun 2019. Dari data yang di dapatakan maka peneliti tertarik untuk meleksanakan penelitian tentang Hubungan Lama Merokok Dengan Kejadian Hipertensi di Puskesmas Kenyaran Kecamatan Pantan Cuaca Kabupaten Gayo Lues.

\section{RESEARCH METHOD}

Penelitian ini menggunakan desain penelitian cross sectional. Penelitian ini dilakukan di Puskesmas Kenyaran Kecamatan Pantan Cuaca Kabupaten GayoLues. Penelitian dilakukan dimulai dari tanggal 11-16 Februari 2019. Populasi yang menjadi fokus penelitian ini adalah penderita hipertensi di Puskesmas Kenyaran Kecamatan Pantan Cuaca Kabupaten Gayo Lues dan dari hasil pengambilan data awal di dapatkan populasi sejumlah 30 orang. Teknik sampling yang digunakan pada penelitian ini adalah Total sampling. Total sampling digunakan dalam penelitian ini karena pengambilan sampel dilakukan dengan menggunakan seluruh populasi yaitu seluruh pasien hipertensi berjumlah 30 orang. Analisa statistik yang digunakan dengan chi-square.

\section{RESULTS AND ANALYSIS}

\subsection{Hasil}

Tabel 1. Data Demografi Responden Puskesmas Kenyaran Kecamatan Pantan Cuaca Kabupaten Gayo Lues

\begin{tabular}{cccc}
\hline No & Data Demografi & Frekuensi & Persentase(\%) \\
\hline \multirow{1}{*}{1} & Umur & & \\
\cline { 2 - 4 } & $17-25$ tahun & 5 & 16,7 \\
\cline { 2 - 4 } & $26-35$ tahun & 16 & 53,3 \\
\cline { 2 - 4 } & $>35$ tahun & 9 & 30,0 \\
\hline \multirow{2}{*}{2} & Jumlah & $\mathbf{3 0}$ & $\mathbf{1 0 0 \%}$ \\
\cline { 2 - 4 } & Pendidikan & 11 & 36,7 \\
\cline { 2 - 4 } & SD & 8 & 26,7 \\
\cline { 2 - 4 } & SMP & 7 & 23,3 \\
\cline { 2 - 4 } & SMA & 4 & 13,3 \\
\cline { 2 - 4 } & Sarjana & $\mathbf{3 0}$ & $\mathbf{1 0 0 \%}$ \\
\hline
\end{tabular}




\begin{tabular}{|c|c|c|c|}
\hline \multirow[t]{6}{*}{3} & Pekerjaan & & \\
\hline & PNS & 2 & 6,7 \\
\hline & Karyawan Swasta & 17 & 56.7 \\
\hline & Wiraswasta & 5 & 16,7 \\
\hline & IRT & 6 & 20.0 \\
\hline & Jumlah & 30 & $100 \%$ \\
\hline
\end{tabular}

Berdasarkan tabel 1 di atas data demografi responden Puskesmas Kenyaran Kecamatan Pantan Cuaca Kabupaten Gayo Luesmayoritas ibu berusia 17-25 tahun sebanyak 16 orang (53,3\%), mayoritas berpendidikan SD sebanyak 11 orang $(36,7 \%)$. Bekerja sebagai IRT sebanyak 6 orang (20.0\%).

Distribusi Frekuensi Lama Merokok di Puskesmas Kenyaran Kecamatan Pantan Cuaca Kabupaten Gayo Lues Tahun 2019

Distribusi Frekuensi lama merokok di Puskesmas Kenyaran Kecamatan Pantan Cuaca Kabupaten Gayo Lues Tahun 2019 dapat dilihat pada tabel berikut ini:

Tabel 2. Distribusi Frekuensi Lama Merokok di Puskesmas Kenyaran Kecamatan Pantan Cuaca Kabupaten Gayo Lues Tahun 2019

\begin{tabular}{cccc}
\hline No & Lama merokok & Frekuensi & \% \\
\hline 1 & Ringan & 6 & 20,0 \\
\hline 2 & Sedang & 10 & 33,3 \\
\hline 3 & Berat & 14 & 46,7 \\
\hline & Jumlah & $\mathbf{3 0}$ & $\mathbf{1 0 0}$
\end{tabular}
$(46.7 \%)$

Berdasarkan tabel 2 di atas terdapat lama merokok responden mayoritas berat sebanyak 14 orang

Distribusi Frekuensi Kejadian Hipertensi di Puskesmas Kenyaran Kecamatan Pantan Cuaca Kabupaten Gayo Lues Tahun 2019

Distribusi Frekuensi Kejadian Hipertensi di Puskesmas Kenyaran Kecamatan Pantan Cuaca Kabupaten GayoLues Tahun 2019 pada tabel 3 di bawah ini:

Tabel 3 Distribusi Frekuensi Kejadian Hipertensi Di Puskesmas Kenyaran Kecamatan Pantan Cuaca Kabupaten Gayo Lues Tahun 2019

\begin{tabular}{cccc}
\hline No & Kejadian Hipertensi & Frekuensi & \% \\
\hline 1 & Ringan & 8 & 26.6 \\
\hline 2 & Sedang & 10 & 33.3 \\
\hline 3 & Berat & 12 & 40.0 \\
\hline & Jumlah & $\mathbf{3 0}$ & $\mathbf{1 0 0}$ \\
\hline
\end{tabular}

Berdasarkan tabel 3 di atas terdapat kejadian hipertensi berat sebanyak 12 orang $(40.0 \%)$.

Data Distribusi Frekuensi Lama Merokok Dengan Kejadian Hipertensi Di Puskesmas Kenyaran Kecamatan Pantan Cuaca Kabupaten Gayo Lues Tahun 2019

Adapun hasil data hubungan lama merokok dengan kejadian hipertensi di Puskesmas Kenyaran Kecamatan Pantan Cuaca Kabupaten Gayo Lues Tahun 2019 dapat dilihat pada tabel berikut:

Tabel 4. Distribusi Frekuensi Hubungan Lama Merokok Dengan Kejadian Hipertensi Di Puskesmas Kenyaran Kecamatan Pantan Cuaca Kabupaten Gayo Lues Tahun 2019

\begin{tabular}{|c|c|c|c|c|c|c|c|c|c|c|}
\hline \multirow[t]{3}{*}{ No } & \multirow{3}{*}{ Lama Merokok } & \multicolumn{6}{|c|}{ KejadianHipertensi } & \multirow{2}{*}{\multicolumn{2}{|c|}{ Total }} & \multirow[t]{3}{*}{$\mathbf{P}$} \\
\hline & & \multicolumn{2}{|c|}{ Ringan } & \multicolumn{2}{|c|}{ Sedang } & \multicolumn{2}{|c|}{ Berat } & & & \\
\hline & & $\mathbf{N}$ & $\%$ & $\mathbf{N}$ & $\%$ & $\mathbf{N}$ & $\%$ & $\mathbf{N}$ & $\%$ & \\
\hline 1 & Ringan & 3 & 10.0 & 2 & 6.6 & 1 & 3.3 & 6 & 20 & 0,001 \\
\hline 2 & Sedang & 3 & 10.0 & 5 & 16.6 & 2 & 6.6 & 10 & 33.3 & \\
\hline 3 & Berat & 2 & 6.6 & 3 & 10.0 & 9 & 30.0 & 14 & 46.6 & \\
\hline & Total & 8 & 26.6 & 10 & 33.3 & 12 & 40 & 30 & 100 & \\
\hline
\end{tabular}

Berdasarkan tabel 4 di atas dapat lama merokok mayoritas sebanyak 14 orang (46.4\%) terdapat kejadian hipertensi berat sebanyak 9 orang $(30.0 \%)$ dan lama merokok ringan sebanyak 6 orang $(20.0 \%)$ terdapat hipertensi ringan sebanyak 3 orang $(10.0 \%)$. 
Berdasarkan uji chi-square diperoleh nilai signifikan p value $(0,001)<(0,05)$ ada hubungan yang signifikan antara lama merokok dengan kejadian hipertensi di Puskesmas Kenyaran Kecamatan Pantan Cuaca Kabupaten Gayo Lues Tahun 2019.

\subsection{Pembahasan}

Hasil Bivariat

Lama Merokok di Puskesmas Kenyaran Kecamatan Pantan Cuaca Kabupaten Gayo Lues Tahun 2019

Merokok merupakan salah satu kebiasaan hidup yang dapat mempengaruhi kesehatan pembuluh darah. Pada keadaan merokok, pembuluh darah di beberapa bagian tubuh akan mengalami penyempitan, dalam kondisi ini dibutuhkan tekanan yang lebih tinggi supaya darah dapat mengalir ke organ-organ tubuh dengan jumlah yang tetap. Untuk itu jantung harus memompa darah lebih kuat, sehingga tekanan pada pembuluh darah meningkat. Efek merokok akan mengakibatkan vasokonstriksi pada pembuluh darah perifer dan pembuluh di ginjal sehingga terjadi peningkatan tekanan darah (Dadang, 2010). Berdasarkan tabel 3 terdapat lama merokok responden di Puskesmas Kenyaran Kecamatan Pantan Cuaca Kabupaten Gayo Lue Tahun 2019 mayoritas berat.

Berdasarkan Karakteristik Pendidikan sebagian besar responden yakni berpendidikan bawah (SD/SMP). Dari pernyataan beberapa resonden menyatakan bahwa tidak pernah diberikan penyuluhan oleh petugas kesehatan terutama perawat tentang dampak rokok terhadap kesehatan sehingga ini hampir pasti dapat berdampak negatif pada perilakunya. Sikap negatif mengenai merokok masih dapat diubah bila individu mendapat masukan-masukan, pengalaman, atau perilaku lingkungan positif yang tidak mendukung perilaku merokok (Linda, 2010).

\section{Kejadian Hipertensi di Puskesmas Kenyaran Kecamatan Pantan Cuaca Kabupaten Gayo Lues Tahun} 2019

Definisi Hipertensi atau tekanan darah tinggi adalah peningkatan tekanan darah sistolik lebih dari $140 \mathrm{mmHg}$ dan tekanan darah diastolik lebih dari $90 \mathrm{mmHg}$ pada dua kali pengukuran dengan selang waktu lima menit dalam keadaan cukup istirahat/tenang. Peningkatan tekanan darah yang berlangsung dalam jangka waktu lama (persisten) dapat menimbulkan kerusakan pada ginjal (gagal ginjal), jantung (penyakit jantung koroner) dan otak (menyebabkan stroke) bila tidak dideteksi secara dini dan mendapat pengobatan yang memadai. Banyak pasien hipertensi dengan tekanan darah tidak terkontrol dan jumlahnya terus meningkat. Oleh karena itu, partisipasi semua pihak, baik dokter dari berbagai bidang peminatan hipertensi, pemerintah, swasta maupun masyarakat diperlukan agar hipertensi dapat dikendalikan (KemenkesRI, 2017).

Berdasarkan tabel 4 diatas di Puskesmas Kenyaran Kecamatan Pantan Cuaca Kabupaten Gayo Lues Tahun 2019 terdapat kejadian hipertensi berat. Hal ini didukung oleh data demografi responden yang berpendidikan SD, Karena semakin tinggi pendidikan responden maka semakin banyak pengetahuan dan informasi yang akan diterima responden dalam menjalani kehidupan. Hasil penelitian ini tidak sesuai dengan hasil penelitian yang dilakukan oleh (Nurhidayat, 2015), menunjukan tidak ada hubungan yang bermakna antara pendidikan rendah dan menengah atas dengan kepatuhan dalam melaksanakan kepatuhan berobat penderita jantung koroner.

Penelitian yang dilakukan oleh (Petch, 2011) memperkuat bahwa tingkat pendidikan dengan jantung koroner tidak ada hubungan antara pendidikan dengan jantung koroner. Hal ini disebabkan tidak selamanya pasien yang berpendidikan dasar tingkat pengetahuannya tentang penyakit jantung koroner rendah dan juga tidak semuanya pasien yang berpendidikan menengah keatas tingkat pengetahuannya tentang penyakit jantung koroner tinggi.

\section{Hubungan Lama Merokok Dengan Kejadian Hipertensi Di Puskesmas Kenyaran Kecamatan Pantan CuacaKabupaten Gayo Lues Tahun 2019}

Berdasarkan uji chi-square diperoleh nilai signifikan p value $(0,001)<(0,05)$ ada hubungan yang signifikan antara lama merokok dengan kejadian hipertensi di Puskesmas Kenyaran Kecamatan Pantan Cuaca Kabupaten Gayo Lues Tahun 2019. Hal ini sejalan dengan hasil penelitian (Linda, 2010). Dari hasil analisis yang memperoleh nilai $\mathrm{p}=0,006<0,05$. Hasil penelitian ini berarti semakin lama responden merokok semakin tinggi tingkat hipertensinya.

Dikatakan risiko tinggi jika responden merokok $\geq 15$ batang perhari dan dikatakan risiko rendah jika responden merokok $<25$ batang perhari. Dampak merokok akan terasa setelah 10-20 tahun. dalam penelitian ini kebanyakan lama merokoknya lebih dari >20 tahun. Sehingga pada penelitian ini diketahui bahwa derajat hipertensi mereka meningkat sehingga mereka sangat beresiko menderita hipertensi stadium III. Selain itu, lebih banyak yang merokok >15 batang perhari. Berdasarkan hasil analisis dapat diketahui bahwa yang merokok $>15$ batang berisiko menderita derajat hipertensi yang lebih tinggi di banding yang merokok, $<15$ batang dalam sehari. (Linda, 2010). 
Zat yang terdapat dalam rokok dapat merusak lapisan dinding arteri berupa plak. Ini menyababkan penyempitan pembuluh darah arteri yang dapat meningkatkan tekanan darah. Kandungan nikotinnya bisa meningkatkan hormone epinefrin yang bias menyempitan pembulu h darah arteri. Karbon monoksidanya dapat menyebabkan jantung bekerja lebih keras untuk menggantikan pasokan oksigen ke jaringan tubuh. Kerja jantung yang lebih keras tantu dapat meningkatkan tekanan darah. Berbagai penelitian membuktikan rokok beresiko terhadap jantung dan pembulu darah (Aggie \& Herbert, 2012).

Semakin lama seseorang menghisap rokok maka akan mempunyai pengaruh besar terhadap kenaikan tekanan darah atau hipertensi. Hal ini dapat disebabkan karena gas CO yang dihasilkan oleh asap rokok dapat berpengaruh besar terhadap kenaikan tekanan darah. Jika di komsumsi terus menerus maka akan menumpuk didalam dinding pembuluh darah dan menyebabkan pembuluh darah "kramp" sehingga tekanan darah naik, peningkatan ini terjadi karena nikotin menyempitkan pembuluh darah sehingga memaksa jantung untuk bekerja keras. Sebagai hasilnya kecepatan jantung dan tekanan darah meningkat (Yashinta, 2015).

\section{CONCLUSION}

1. Terdapat lama merokok responden di Puskesmas Kenyaran Kecamatan Pantan Cuaca Kabupaten Gayo Lues Tahun 2019 mayoritas berat.

2. Di Puskesmas Kenyaran Kecamatan Pantan Cuaca Kabupaten Gayo Lues Tahun 2019 terdapat kejadian hipertensi berat.

3. Berdasarkan uji chi-square diperoleh nilai signifikan $p$ value $(0,001)<(0,05)$ ada hubungan yang signifikan antara lama merokok dengan kejadian hipertensi di Puskesmas Kenyaran Kecamatan Pantan Cuaca Kabupaten Gayo Lues Tahun 2019.

\section{REFERENCES}

Abiding. U.w. dan nawi, arsin,a.a. Factor Resiko Yang Berhubungan Dengan Kejadian Hipertensi Di Rsud Polewali Kabupaten Polewali Mandar. 2011. hhtp:///118.97.33.150/jurnal/files/09179210095ebledlele a316c2cfa b06.pdf. di. Akses tanggal 23 november 2015.

Departemen Kesehatan Republik Indonesia. Riset Kesehatan Dasar 2013. Jakarta: Badan Penelitian dan Pengembangan Kesehatan Departemen Kesehatan, Republik Indonesia. 2013.

Juliyah. Di Indonesia 300 Ribu Kematian Pertahun Akibat Rokok. 2012. Diakses tanggal 10 Agustus 2015 dari http://infopublik.kominfo.go.id.

Kusuma, A. R. P. Pengaruh Merokok Terhadap Kesehatan Gigi Dan Rongga Mulut. Kedokteran Gigi Universitas Islam Sultan Agung. 2012. Diakses dari: http://unissula.ac.id/newver/images. /jurnal/Juli/andina\%20 diaksestanggal 02 juli 2015. Jendela Data Dan Informasi Kesehatan 2012 .

Kementrian Kesehatan Republik Indonesia. Penyakit tidak menular. Bulletin Jendela Data Dan Informasi Kesehatan 2012.

Linda Dwi Astuti. Hubungan Antara Perokok Dengan Kejadian Hipertensi Pada Lansia Di Dusun Gatak Desa Tamantirto Kasihan Bantul Yogyakarta. 2010. http://www.google.co.id/search?hl. $=$ in\&redir_esc $=\&$ client $=$ msandroidsamsung\&source $=$ andridlauncherwidget $\& v=133247963 \& q s u b t s=12$ 29300185966\&action=devloc\&q=hasil+survei+penyakit+hipertensi+di+gowa\&v133247963di/akses_07 - 07-2015.

Nursalam. Metodologi Penelitian Ilmu Keperawatan: Pendekatan Praktis, Edisi 3, Salemba Medika. 2013.

Sukmaningsih, A. A. Penurunan Jumlah Spermatosit Pakiten Dan Spermatid Tubulus Seminiferus Testis Pada Mencit (Mus Musculus) Yang Di paparkan Asap Rokok. Universitas Udayana. 2009. Diakses di:http://ejournal.unud.ac.id/abstrak/artikel_1. pdf tanggal 10 Agustus 2015.

Yashinta Octavian G.S. dkk. Hubungan Merokok Dengan Kejadian Hipertensi Pada Laki-Laki Usia 35-65 Tahun Di Kota Padang. 2015. http://jurnal.fk.unand.ac.id Jurnal Kesehatan Andalas. 2015.

Prawira. B. Jumlah Perokok Di Indonesia Merokek. 2011 Di Ambil Pada 28 Desember $2015 . \quad$ Dari http://nad.bkkbn.go.id/berita/423/.

Sujarweni, V. Wiratna. 2014. Metode Penelitian: Lengkap, Praktis, dan Mudah Dipahami. Yogyakarta: Pustaka Baru Press.

Kementrian Kesehatan Republik Indonesia. Penyakit tidak menular. Bulletin.

Nursalam. 2018. Konsep dan Penerapan Metodologi Penelitian Ilmu Keperawatan. Jakarta: Salemba Medika.

Sugiyono. Metode Penelitian Kuantitatif, Kualitatif dan R \& D. Bandung: Alfabeta. 2014. 